\title{
Is there any relationship between $H$. pylori gastritis and mucosal esophagitis?
}

\section{H. pylori gastriti ve mukozal özefajit arasında bir ilişki var mı?}

\author{
Elif Sag ${ }^{1}$, Burcu Guven ${ }^{1}$, Murat Cakir ${ }^{1}$ \\ ${ }^{1}$ Dept. of Pediatric Gastroenterology, Hepatology and Nutrition, Karadeniz Technical University, Faculty of Medicine, Trabzon, Turkey
}

\begin{abstract}
Background Gastroesophageal reflux disease (GERD) and H.Pylori gastritis are common seen in childhood. In the literature, it was found that the incidence of $H$. pylori infection in patients with GERD was between 30-90\%. Coexistence of two diseases is one of the topic and controversial issue in these days. In our study; we aimed to assess the prevalence of GERD in pediatric patients with and without H. pylori gastritis, and investigate whether H. pylori infection is a risk factor for GERD.

Methods The patients undergoing endoscopic examination in Karadeniz Technical University, Faculty of Medicine, Pediatric Gastroenterology, Hepatology and Nutrition clinic between January 2009 - January 2019 included in the study. The data of patients were recorded from the hospital files retrospectively. The patients were divided in two groups according to whether H. pylori infection positive and negative. GERD frequency, indication of endoscopy and demographic characteristics were compared.

Results Among the 4337 patients (55.5\% female, mean age \pm SD; $9.5 \pm 4.4$ years, range; 6 months-19 years), 348 patients (8\%) had GERD, and 779 patients (18\%) had H. pylori gastritis. There was no significant difference in gender between patients with $H$. pylori positive and negative ( $p>0.05)$. We determined that the age of patients with $H$. pylori gastritis was older $(\mathrm{p}=0.000)$. The prevalence of GERD in the $H$. pylori negative patients was $8.4 \%$ compared to $6.2 \%$ in the H. pylori positive patients [OR, $0.7195 \% \mathrm{CI}(0.52-0.98), \mathrm{p}=0.030$ ].

Conclusions Our study showed that $H$. pylori infection had a protector role for GERD. We could not evaluate the patients reflux symptoms after H. pylori eradication therapy. Therefore, further prospective studies are needed.
\end{abstract}

Key words: Helicobacter pylori, gastroesophageal reflux disease, child

\section{O̊zet}

Amaç Gastroözofageal reflü hastalığı (GÖRH) ve H. pylori gastriti çocukluk çağında sık görülmektedir. Literatürde GÖRH olan hastalarda H. pylori enfeksiyonu insidansının \% 30-90 arasında olduğu bildirilmiştir. İki hastalığın bir arada bulunması, günümüzde tartışılan konuların başında gelmektedir. Çalışmamızda; H. pylori gastriti olan ve olmayan çocuk hastalarda GÖRH prevelansını bulmayı ve H. pylori enfeksiyonunun GÖRH için bir risk faktörü olup olmadı̆̆ını araştırmayı amaçladık.

Yöntem Çalışmaya Ocak 2009-Ocak 2019 arasında Karadeniz Teknik Üniversitesi Tıp Fakültesi Çocuk Gastroen-

Corresponding author: Elif Sag, Dept. of Pediatric Gastroenterology, Hepatology and Nutrition, Karadeniz Technical University, Faculty of Medicine, Trabzon, Turkey, Phone: +905465805086, E-mail:drturkmen61@gmail.com

Received: 13 March 2019 Accepted: 29 March 2019

Conflicts of Interest: None

Funding: None 
teroloji, Hepatoloji ve Beslenme kliniğinde endoskopik inceleme yapılan hastalar dahil edildi. Hastaların verileri hastane dosyalarından geriye dönük olarak kaydedildi. Hastalar H. pylori enfeksiyonunun pozitif ve negatif olup olmamasına göre iki gruba ayrıldı. GÖRH sıklığı, endoskopi endikasyonları ve demografik özellikler karşılaştırıldı.

Bulgular 4337 hastanın (\%55.5'i kız, ortalama yaş \pm SD; $9.5 \pm 4.4$ yll, yaş aralı̆̆ $; 6$ ay-19 yıl), 348'inde (\%8) GÖRH, 779'unda (\%18) H. pylori gastiriti tespit edildi. H. pylori pozitif ve negatif olan hastalar arasinda cinsiyet açısından anlamlı fark yoktu $(\mathrm{p}>0.05)$. H. pylori gastritinin daha büyük çocuklarda olduğu tespit edildi $(\mathrm{p}=0.000)$. H. pylori negatif hastalarda GÖRH prevalansı $\% 8.4$ iken H. pylori pozitif hastalarda \%6.2 idi [OR, $\% 0.7195 \%$ CI (0.52-0.98), p=0.030].

Sonuç Çalışmamız H. pylori enfeksiyonunun GÖRH'de koruyucu bir rolü olduğunu göstermektedir. H. pylori eradikasyon tedavisinden sonra hastaların reflü semptomları değerlendirilememiştir. Bu nedenle ileriye dönük daha geniş spektrumlu çalışmalara ihtiyaç vardır.

Anahtar kelimeler: Helicobacter pylori, gastroözofagial reflü hastalı̆̆l, çocuk

\section{Introduction}

Gastroesophageal reflux (GER) is a normal physiologic condition and it may happen several times in the postprandial period for less than three minutes in healthy infants, children, and adults and does not need any treatment. However, in the presence of troublesome symptoms and/or complications such as reflux esophagitis (RE), structures, it is defined as gastroesophageal reflux disease (GERD). ${ }^{1}$ The development of GERD is multifactorial and factors such as infectious agents, nutrition, physical development, stress, physical exertion, genetic predisposition and anatomical anomalies play role in the development of GERD. ${ }^{2}$ The distinguishing GER from GERD is important for treatment decision. It is based on clinic symptoms, physical examination, endoscopy and $\mathrm{pH}$ impedance. ${ }^{3}$

Helicobacter pylori (H. pylori) infection is acquired in childhood, often before the age of five years. It is usually transmitted by fecal-oral, oral-oral or gastro-oral way. ${ }^{4}$
The presence of clinical symptoms or conditions such as duodenal and gastric ulcers, gastric lymphoma, atrophic gastritis with intestinal metaplasia should be treated to eradicate the bacterium. ${ }^{5}$ As a result of studies, it is known that $H$. pylori leads to diseases such as gastric lymphoma, lymphoid nodular hyperplasia and ulcer. However, the role of $H$. pylori infection as a potential protective or / triggering factor in the development of GERD is one of the most controversial issue. There are two opinions according to studies in literature; i) RE occurs because of increased acid secretion due to $H$. pylori, decreased esophageal sphincter pressure, a delay in gastric emptying ${ }^{6}$, ii) the presence of pangastritis or gastritis in the corpus leads to decreased acid secretion with consequent increase in gastrin, increased lower esophageal sphincter pressure, and this opinion explains the inverse relationship between $H$. pylori infection and GERD. ${ }^{7}$ In the literature, it was found that the incidence of H. pylori infection in patients with GERD was between $30-90 \%{ }^{8}$

In this study; we aimed to assess the prevalance of GERD in pediatric patients with and without $H$. pylori gastritis, and investigate whether $H$. pylori infection is a risk factor for GERD.

\section{Methods}

We included 4893 patients undergoing endoscopic examination in Karadeniz Techinical University, Faculty of Medicine, Pediatric Gastroenterology, Hepatology and Nutrition clinic from January 2009 to January 2019. The demographic characteristics, clinical, laboratory, endoscopic and histopathological findings of patients were recorded from the hospital files retrospectively.

The patients, who were not taken biopsy from esophagus, had active gastroesophageal bleeding during the examination, had neurologic disorders, used any medications for $H$. pylori eradication excluded from the study $(\mathrm{n}=556)$. The endoscopic diagnoses of GERD based on the endoscopic Los Angeles classification (different degrees of erosive esophagitis A, B, C, and D) and/or histopathologic examination (with Giemsa and H\&A stain). H. pylori gastritis diagnosis based on histopathologic ex- 
amination (with Giemsa and H\&A stain). The patients were divided in two groups according to whether $H$. $p y$ lori infection positive and negative. GERD frequency, indication of endoscpoy and demographic characteristics were compared. The study protocol was approved by the institutional Ethics Committee (Ethics Committee no: 2018/284). The study was conducted in accordance with the principles of the Declaration of Helsinki.

At statistical analysis, data were expressed as mean \pm standard deviation (SD) for constant variables and percentages (\%) for categoric variables. At comparison of

Table 1. The demographic features, indication of endoscopy, the prevalence of GERD in patients with $H$. pylori positive and negative.

\begin{tabular}{|c|c|c|c|}
\hline & $\begin{array}{c}\text { H. pylori } \\
\text { positive } \\
\mathrm{n}=779,(\%)\end{array}$ & $\begin{array}{c}\text { H. pylori } \\
\text { negative } \\
\mathbf{n}=3558,(\%)\end{array}$ & $\mathrm{p}$ \\
\hline $\begin{array}{l}\text { Gender, } \\
\text { female, n, (\%) }\end{array}$ & $452(58.2)$ & $1933(54.3)$ & 0.060 \\
\hline $\begin{array}{l}\text { Age, } \\
\text { mean } \pm \text { SD }\end{array}$ & $11.1 \pm 3.9$ & $9.2 \pm 4.5$ & 0.000 \\
\hline GERD, n, \% & $48(6.2)$ & $300(8.4)$ & 0.030 \\
\hline \multicolumn{4}{|l|}{$\begin{array}{l}\text { Indication of } \\
\text { endoscopy }\end{array}$} \\
\hline $\begin{array}{l}\text { Abdominal } \\
\text { pain }\end{array}$ & $619(79.7)$ & $2401(67.4)$ & 0.000 \\
\hline Vomiting & $16(2.1)$ & $205(5.8)$ & \\
\hline Dyspepsia & $35(4.5)$ & $308(8.7)$ & \\
\hline $\begin{array}{l}\text { Growth } \\
\text { retardation }\end{array}$ & $48(5.8)$ & $240(6.7)$ & \\
\hline $\begin{array}{l}\text { Chronic } \\
\text { diarrhea }\end{array}$ & $7(0.9)$ & $74(2.1)$ & \\
\hline Anemia & $28(3.6)$ & $190(5.3)$ & \\
\hline Dysphagia & $5(0.6)$ & $26(0.7)$ & \\
\hline $\begin{array}{l}\text { GIS } \\
\text { bleeding }\end{array}$ & $18(2.3)$ & $94(2.6)$ & \\
\hline $\begin{array}{l}\text { Suspect of } \\
\text { varice }\end{array}$ & $1(0.1)$ & $21(0.6)$ & \\
\hline
\end{tabular}

GERD, gastroesophageal reflux disease group measurement data, Student's t test was used for normally distributed data and the Mann Whitney U test for non-normally distributed data. The chi square test was applied in the comparison of non-measurement categoric data. $\mathrm{p}$ values $\leq 0.05$ were regarded as significant.

\section{Results}

Among the 4337 patients ( $55.5 \%$ female, mean age \pm SD; $9.5 \pm 4.4$ years, range; 6 months- 19 years), 348 patients (8\%) had GERD, and 779 patients (18\%) had H. pylori gastritis. There was no significant difference in gender between patients with $H$. pylori positive and negative ( $>0.05)$. We determined that the age of patients with H. pylori gastritis was older $(\mathrm{p}=0.000)$ (Table 1$)$.

The most common indication for endoscopy was abdominal pain and dyspepsia $(69.6 \%$ and $7.9 \%$, respectively). Among 3020 patients with abdominal pain, $20.5 \%(\mathrm{n}=619)$ of patients had $H$. pylori gastritis, and $6.3 \%(\mathrm{n}=189)$ of patients had GERD ( $\mathrm{p}=0.000, \mathrm{p}=0.000$, respectively).

The prevalence of GERD in the H. pylori negative patients was $8.4 \%$ compared to $6.2 \%$ in the H. pylori positive patients [OR, 0.71 95\% CI (0.52-0.98), p=0.030] (Fig. 1).

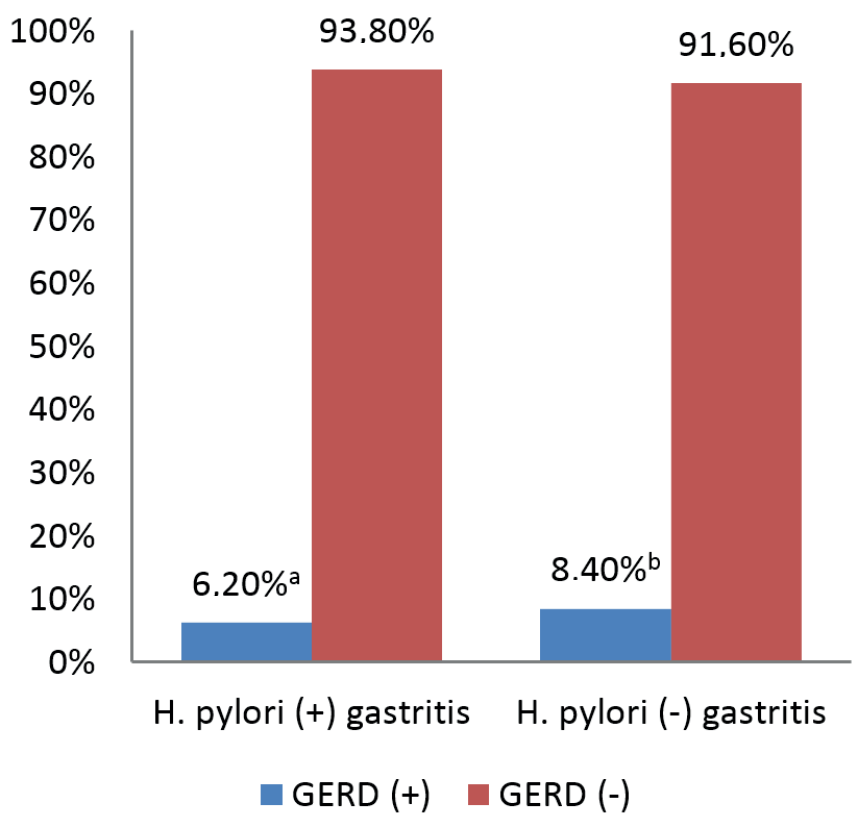

Fig. 1. The prevalence of GERD in the patients with $H$. pylori positive and $H$. pylori negative $\left(\mathrm{p}^{\mathrm{a}-\mathrm{b}}<0.05\right)$. 


\section{Discussion}

In our study, we found that i) H. pylori gastritis was more common in older children, ii) there were no significant differences for $H$. pylori gastritis between gender, iii) abdominal pain was higher in the patients with $H$. pylori gastritis, iv) there was a negative relationship between H. pylori and GERD.

Helicobacter pylori regulates gastric motility through gastric-regulating gastric hormones such as gastrin, ghrelin and motilin..$^{3-5}$ Motilin has a prokinetic role and is secreted by gastrointestinal endocrine cells and increases LES pressure. Ghrelin is secreted by the enteroendocrine cells of gastric mucosa and gastric acid secretion, gastrointestinal motility, and gastric emptying increases due to ghrelin secretion. Gastrin is another hormone which affects gastric motility. It is secreted by antral $G$ cells and affected by H. pylori. Release of these hormones may be changed with $H$. pylori infection. The serum levels of gastrin depend on localization of $H$. pylori infection. In H. pylori -induced corpus-limited gastritis, hypoacidity develops as a result of parietal cell destruction. Increased gastrin releasing occurs because of rebound hyperacidity after eradication therapy. On the other hand, in antrum-limited H. pylori infection leads to destruction of somatostatin secreting cells, hypergastrinemia and hyperacidity occur during the H. pylori infection. ${ }^{7}$ So, according to these theories, we can say that the risk of GERD increases in H. pylori infection. However, the acidity and therefore the risk of GER are only reduced in atrophic gastritis. Ghrelin decrease GERD by affecting LES pressure, and it has been reported that decreased ghrelin increases GERD development. ${ }^{4}$ Unlike these theories, Eren et al reported that there was no significant relationship between gastric-regulating hormones (motilin, ghrelin, and gastrin) and H. pylori infection. They suggested that H. pylori has not any role for development GERD. ${ }^{7}$

There have been controversial studies about the relationship between $H$. pylori and GERD until now. According to Nordenstedt et al; H. pylori has a protective role for GERD through gastric atrophy and decreased acid. ${ }^{2} \mathrm{Wu}$ et al. reported that there were significant differences in the esophageal sphincter pressure or esophageal peristaltic function between $H$. pylori -positive and negative controls. However, they suggested that esophageal motor abnormalities developed as a result of $H$. pylori and its effects on releasing gastric-regulating gastric hormones. ${ }^{6}$ Additionally, some studies claim that the eradication of $H$. pylori infection leads to erosive esophagitis and GERD relapsing. ${ }^{89}$ In a study with adults study; Riberio et al found that there was significant association between $H$. pylori, GERD and gender. ${ }^{10}$ On the contrary, Moon et al analyzed 420 endoscopic examination and found positive association between $H$. pylori and GERD. ${ }^{11}$ In a study on adults; Chourasia et al evaluated 123 patients with GERD and $47.9 \%$ had $H$. pylori infection. They reported that $H$. pylori caused less acidity and a decrease in reflux intensity. ${ }^{12}$

When the studies in the literature are examined; it is seen that $H$. pylori gastritis decreases GERD through gastritis and corpus limited gastritis. In general, atrophic gastritis is often seen in adults and is rarely seen in childhood. However in our cases, the biopsy was usually taken from the antrum and there was antral gastritis. There are not atrophic and corpus limited gastritis in our study. So, we could not explain the inverse relationship between $H$. pylori and GERD by this theory. According to another theory; $\mathrm{H}$. pylori increases the $\mathrm{pH}$ of the stomach by producing ammonia through intragastric urease, and ammonia protects againist to GERD ${ }^{13}$. So, increased the reflux symptoms after $H$. pylori eradication may be explained by this theory. In our study; $H$. pylori is protective againist to GERD and we suggest that increased ammonia and gastric $\mathrm{pH}$ reduce the risk of development GERD. There are some limitations of our study. Firstly, it was a retrospective study. Additionally, gastric biopsies were only taken from antrum. That's why, if there was a H. pylori infection on the other gastric area, we could not determine.

In conclusion, our study showed that H. pylori infection had a protective role for GERD probably through increased ammonia and gastric $\mathrm{pH}$. Since our study was retrospective, we could not evaluate the reflux symp- 
toms of the patients with $H$. pylori after eradication therapy. Therefore, further prospective studies are needed.

\section{References}

1. Rosen R, Vandenplas Y, Singendonk M. et al. Pediatric gastroesophageal reflux clinical practice guidelines: joint recommendation of the North American Society for Pediatric Gastroenterology, Hepatology, and Nutrition and the European Society for Pediatric Gastroenterology, Hepatology, and Nutrition. JPGN 2018;66:516-54.

2. Nordenstedt H, Nilsson M, Johnsen R, Lagergren J, Hveem K. Helicobacter pylori infection and gastroesophageal reflux in a population-based study (The HUNT Study). Helicobacter 2007;12:16-22.

3. Tanaka I, Tatsumi Y, Kodama T, et al. Effect of Helicobacter pylori eradication on gastroesophageal function. J Gastroenterol Hepatol 2004;19:251-7.

4. Nwokolo CU, Freshwater DA, O'Hare P, Randeva HS. Plasma ghrelin following cure of Helicobacter pylori. Gut 2003;52:637-40.

5. Dominguez-Mu-Oz JE, Malfertheiner P. Effect of Helicobacter pylori infection on gastrointestinal motility, pancreatic secretion and hormone release in asymptomatic humans. Scand J Gastroenterol 2001;36:1141-7.

6. Wu JC, Sung JJ, Ng EK, et al. Prevalence and distribution of Helicobacter pylori in gastro-oesophageal reflux disease: a study from the East. Am J Gastroenterol 1999;94:1790-4.

7. Eren M, Colak O, Isiksoy S, Yavuz A. Effect of H. pylori infection on gastrin, ghrelin, motilin, and gastroesophageal reflux. Turk J Gastroenterol 2015;26:367-72.

8. Schenk BE, Kuipers EJ, Klinkenberg-Knol EC, Eskes SA, Meuwissen SG. Helicobacter pylori and the efficacy of omeprazole therapy for gastroesophageal reflux disease. Am J Gastroenterol 1999;94:884-7.

9. Labenz J, Blum AL, Bayerdorffer E, et al. Curing Helicobacter pylori infection in patients with duodenal ulcer may provoke reflux esophagitis. Gastroenterology 1997;112:1442-7.

10. Ribeiro PF, Kubrusly LF, Nassif PA, et al. Relationship between esophagitis grades and Helicobacter pylori. Arq Bras Cir Dig 2016;29:135-7.

11. Moon A, Solomon A, Beneck D, Cunningham-Rundles S. Positive association between Helicobacter pylori and gastroesophageal reflux disease in children. J Pediatr Gastroenterol Nutr 2009;49:283-8.

12. Chourasia D, Misra A, Tripathi S, Krishnani N, Ghoshal UC. Patients with Helicobacter pylori infection have less severe gastroesophageal reflux disease: a study using endoscopy, 24-hour gastric and esophageal pH metry. Indian J Gastroenterol 2011;30:12-21

13. Nam SY. Helicobacter pylori has an inverse relationship with severity of reflux esophagitis. J Neurogastroenterol Motil 2011;17:267-73. 